\title{
PLANEJAMENTO ESTRATÉGICO E INOVAÇÃO: UM ESTUdO DE CASO SOBRE A IMPLEMENTAÇÃO DO SERVIÇO DE LAVAGEM DE MATERIAL CONTAMINADO DE UMA LAVANDERIA NA CIDADE DE NOVA ANDRADINA - MS
}

\author{
Congresso Nacional Online de Empreendedorismo, 3ạ edição, de 06/12/2021 a 08/12/2021
} ISBN dos Anais: 978-65-81152-30-7

MASSON; Fabio Junior ${ }^{1}$, ALVES; Laura Vandeira 2, SILVA; Luiz Claudio Tavares ${ }^{3}$, SERRA; Adriano ${ }^{4}$, OLIVEIRA; Muriel Batista de 5

\section{RESUMO}

A gestão de inovação estabelece métodos para gerar valor as empresas, por meio da concretização de ideias, que inovam uma pré-existente, ou que tiram projetos dos papeis. É responsável por sistematizar o processo de inovação nas empresas, determinando quantas etapas, quais as rotinas, recursos humanos, materiais, financeiros e tecnológicos serão aplicados nele, estabelecendo a estrutura que será adotada para realizá-lo e gerar resultados. No mundo atual, globalizado, onde os clientes estão cada vez mais exigentes e a oferta de produtos e serviços cada vez mais vasta, inovar se tornou uma questão essencial para que as empresas não percam em competitividade ou venham a fechar as portas por não mais satisfazer seus clientes. Das menores às maiores empresas, todas vem buscando alcançar a inovação e gerindo projeto para alcançar a mesma, e algumas organizações até se denominam inovadoras. Porém para a academia existem diversas definições para a inovação e delimitações desse processo de gestão que devem ser conhecidas antes de colocá-la em prática, para que os objetivos em questão sejam realmente alcançados. O presente trabalho apresenta a relação entre gestão de inovação, planejamento estratégico e gestão de projetos, buscando explicá-la e demonstrar a aplicação desses termos na prática realizando um estudo de caso sobre a implantação do serviço de lavagem de material contaminado na lavanderia V.L, localizada na cidade de Nova Andradina - MS, região rodeada porpostos de gasolina, usinas de açúcar e álcool e frigoríficos. Tal estudo de caráter qualitativo e quantitativo foi realizado para fins estratégicos, levantando caraterísticas da empresa e quantificando equipamentos e valores, para analisar se existia a viabilidade da empresa atender a demanda da região em atendimento a NR 6, na intenção de que a V.L lave os uniformes profissionais, caracterizados pela norma regulamentadora citada, como EPIs. Como resultados do serviço estudado encontrou-se uma possibilidade de reduzir o custo total da empresa em $71 \%$ onde o custo para a lavagem de cada peçaera de $\mathrm{R} \$ 2,33$ passando a custar para a empresa $\mathrm{R} \$ 1,65$ após a implantação doserviço. A partir dos resultados apresentados, pode-se concluir que será sim viável aimplantação dessa nova prestação de serviço. Porém ainda serão precisos muitos estudos para decidir qual a melhor forma de tratar o efluente que será gerado pela nova atividade da empresa, uma vez visto que os artigos e pesquisas encontradas, dentro de 18 meses de pesquisa, ainda não trouxeram respostas satisfatórias. 
PALAVRAS-CHAVE: inovação, planejamento, gestão 